National Mapping Program

Technical Instructions

Data Users Guide 7

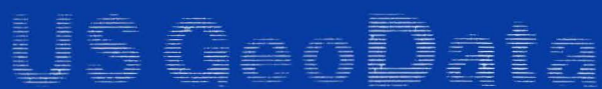

\section{Alaska Interim Land Cover Mapping Program}

Data Users Guide 


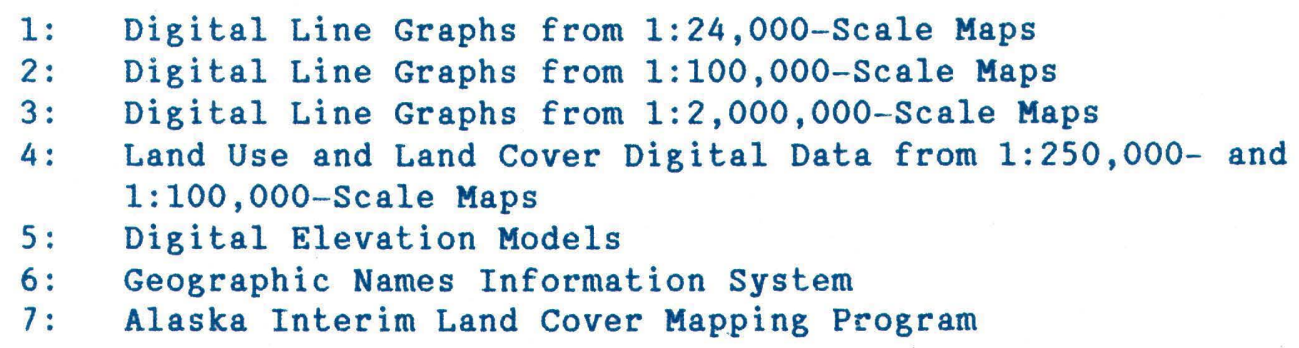

Data Users Guides 1-7 generally replace the Geological Survey Circular 895.

Questions regarding availability and ordering of US GeoData (all types of digital cartographic and geographic data produced and distributed by the U.S. Geological Survey) should be addressed to:

User Services Branch

National Cartographic Information Center

U.S. Geological Survey

507 National Center

Reston, Virginia 22092

(703) 860-6045

Technical questions and comments should be addressed to:

Branch of Technical Management

U.S. Geological Survey

510 National Center

Reston, Virginia 22092 
UNITED STATES

DEPARTMENT OF THE INTERIOR

U.S. GEOLOGICAL SURVEY

ALASKA INTERIM LAND COVER MAPPING PROGRAM

Data Users Guide 7

Property d:

Don Kulow Library

EROS Data Centor

Sioux Falls, SD 57198

Reston, Virginia

1987 
Susan P. Benjamin of Technicolor Government Services, Inc., was responsible for designing the format of data from the Alaska Interim Land Cover Mapping Program to meet the specifications developed by the Landsat Ground Station Operators Working Group (Landsat-D CCT standards committee, 1979). Leonard Gaydos of the U.S. Geological Survey suggested adoption of those specifications to insure that complete documentation of the data would be available on tape in an easy to use format. 


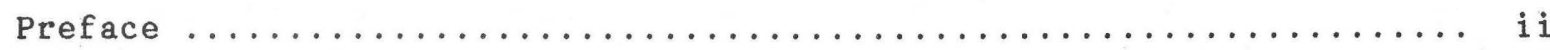

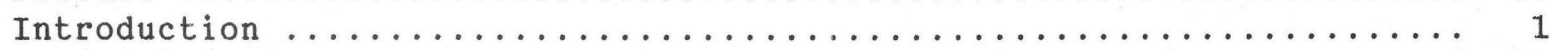

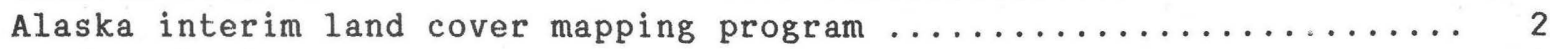

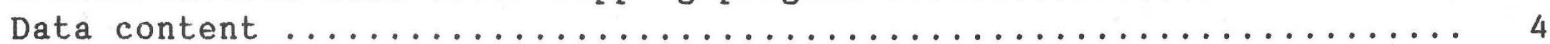

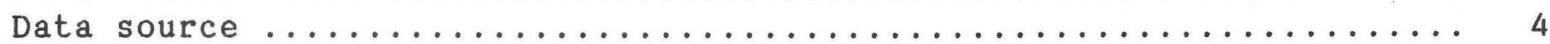

Data structure ................................. 4

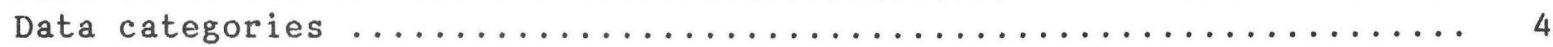

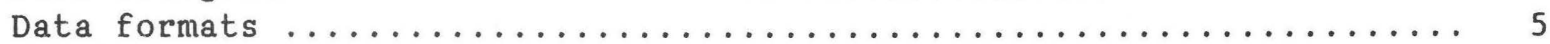

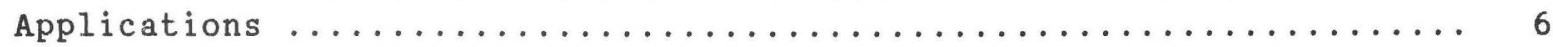

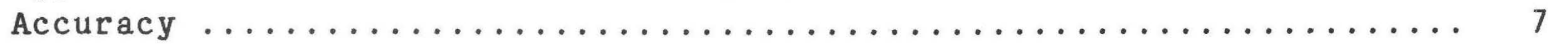

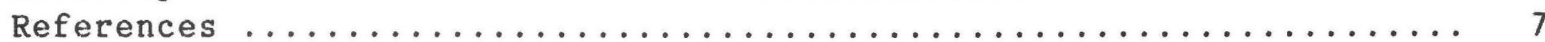

Appendix - Record format specifications .................. 10

ILLUSTRATION

Page

Figure 1. Structure of Alaska land cover data .............. 5

TABLE

Page

Table 1. Interim classification system for Alaska ............ 3 


\section{INTRODUCTION}

The National Cartographic Information Center (NCIC) distributes digital cartographic/geographic data files produced by the U.S. Geological Survey (USGS) as part of the National Mapping Program. Digital cartographic data files may be grouped into four basic types. The first of these, called a Digital Line Graph (DLG), is the line map information in digital form. These data files include information on planimetric base categories, such as transportation, hydrography, and boundaries. The second type, called a Digital Elevation Model (DEM), consists of a sampled array of elevations for a number of ground positions that are usually at regularly spaced intervals. The third type is Land Use and Land Cover digital data, which provide information on nine major classes of land use such as urban, agricultural, or forest as well as associated map data such as political units and Federal land ownership. The fourth type, the Geographic Names Information System, provides primary information for all known places, features, and areas in the United States identified by a proper name.

The digital cartographic data files from selected quadrangles currently available from NCIC include the following:

- Digital Line Graphs (DLG)

$-\ldots 1: 2,000,000-$ scale maps

- -7.5- and 15-minute topographic quadrangle series

$-1: 100,000-$ scale quadrangle series

- Digital Elevation Models (DEM)

--7.5-minute topographic quadrangle series

--1-degree quadrangle coverage

- Land Use and Land Cover digital data

- -1:250,000- and 1:100,000-scale land use and land cover and associated maps

- 1:250,000-scale Alaska Interim Land Cover Maps

- Geographic Names

Any use of trade names and trademarks in this publication is for identification purposes only and does not constitute endorsement by the U.S. Geological Survey. 
The digital data are useful for the production of cartographic products such as plotting base maps and for various kinds of spatial analysis. A major use of these digital cartographic/geographic data is to combine them with other geographically referenced data enabling scientists to conduct automated analyses in support of various decision making processes.

This document describes digital land cover data prepared from analyzing Landsat multispectral scanner data. The data consist of digital land cover codes for 50-meter cells based on the Universal Transverse Mercator (UTM) grid. Each data set contains land cover data for one 1:250,000scale quadrangle. They can be used to produce a variety of products having applications for land management, wildlife habitat studies, geomorphology, hydrology, or related fields. The data differ from other land cover data distributed by NCIC in several ways:

- They are available in cellular form rather than polygons.

- 1:250,000-scale land cover maps have been prepared from the digital data, rather than the digital data being generated from a map.

- Land cover is mapped according to a system unique to Alaska.

\section{ALASKA INTERIM LAND COVER MAPPING PROGRAM}

In order to meet the requirements of the Alaska National Interest Lands Conservation Act (ANILCA) for comprehensive resource and management plans from all major land management agencies in Alaska, the USGS has begun a program to classify land cover for the entire state using Landsat digital data.

Vegetation and land cover classifications, generated in cooperation with other agencies, currently exist for 115 million acres of Alaska. Using these as a base, the USGS has prepared a comprehensive plan for classifying the remaining areas of the state. The development of this program will lead to a complete interim vegetation and land cover classification system for Alaska and allow the dissemination of digital data for those areas classified.

At completion, 153 Alaska 1:250,000-scale quadrangles will be published and will include land cover from digital Landsat classifications, statistical summaries of all land cover by township, and computer-compatible tapes. An interagency working group has established an Alaska classifi-

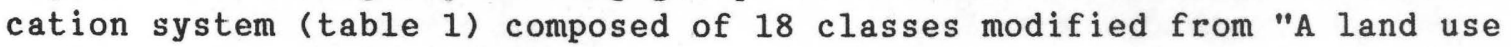
and land cover classification system for use with remote sensor data" (Anderson and others, 1976), and from "Revision of a preliminary classification system for vegetation of Alaska" (Viereck and Dyrness, 1982) for the unique ecoregions which are found in Alaska. 
Table 1.-- Interim classification system for Alaska

Class

Class Number

I. Forest

(forest canopy of

one third or more)

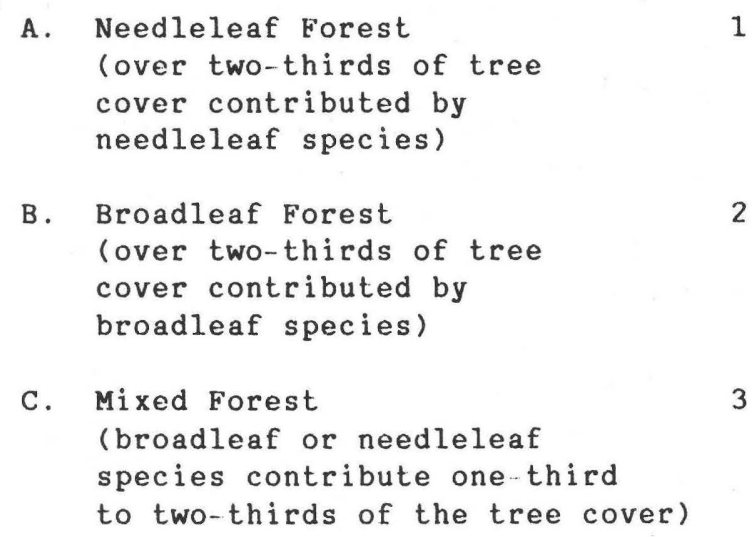

A. Needleleaf Forest 1

(over two-thirds of tree

cover contributed by

needleleaf species)

B. Broadleaf Forest

(over two-thirds of tree

cover contributed by

broadleaf species)

C. Mixed Forest

(broadleaf or needleleaf

species contribute one third

to two-thirds of the tree cover)

II. Shrubland

(forest canopy

cover of less than

one-third and shrub

canopy cover of

one third or more)
A. Tall and Low Shrubland
B. Dwarf Shrubland
and related communities
(rarely exceeding $50 \mathrm{~cm}$
in height)

4

III. Herbaceous Vegetation (vegetation with $5 \%$ or more of vascular and non-vascular [mosses and lichens] cover and less than one-third cover of woody plants)

A. Dry or moist Herbaceous 6

B. Wet Herbaceous 7

C. Aquatic Herbaceous 8

D. Mosses 9

E. Lichens 10

IV. Agriculture $\quad 11$

V. Urban land $\quad 12$

VI. Barren land
A. Sparse vegetation
B. Nonvegetated

VII. Water
A. Clear and/or Deep
B. Turbid and/or Shallow

VIII. Ice, Snow, and Clouds

IX. Shadow 
Each Alaska Interim Land Cover Mapping Program tape contains data for one $1: 250,000$-scale quadrangle (1 degree of latitude by either 2 or 3 degrees of longitude) and the area immediately surrounding it.

The data describe polygons of the land cover classes described in table 1. Each data set contains a subset of all of the possible data classes. In addition to the land cover data, format specification and documentation information are supplied.

\section{DATA SOURCE}

Landsat Earth observation satellites provide the primary source data. A multispectral scanner on Landsat measures and records intensity of reflected light in four wavelength bands for areas on the ground measuring approximately $57 \times 79$ meters. A computer is used to sort these multispectral readings into a number of spectral classes, then to classify each area sensed (referred to as a pixel, or picture element) into one of the classes. These spectral classes are interpreted by a data analyst who associates each with a land cover class. Other steps are taken to register the data to map coordinates, mosaic data from adjacent Landsat scenes, and edit the resulting data.

\section{DATA STRUCTURE}

The Alaska land cover data are structured in a raster cell format. The area mapped on each 1:250,000-scale quadrangle is divided into a matrix of equal-size cells (pixels), resampled in size and orientation from the original Landsat image pixels. The result is a rectangular array (rows and columns) of land cover data where each pixel represents a ground area of $50 \times 50$ meters.

Land cover data are registered and resampled to a UTM grid in a separate process for each quadrangle. Pixel values going down a column of data represent land cover at 50-m intervals along a UTM northing; likewise, pixel values across a row of data represent land cover at $50-\mathrm{m}$ intervals along a UTM easting (fig. 1).

\section{DATA CATEGORIES}

Landsat scene analysis to create the classified data sets is performed by the EROS Data Center Alaska Field office (AFO) and by the Geographic Investigations Section (GIS) of the Western Mapping Center. Map products are prepared from the digital data.

Each pixel in a land cover data set is identified by one of the Alaska Interim Classification System land cover class numbers (table 1) to indicate its land cover assignment. Adjacent pixels containing the same class number combine to make up the polygons of land cover data printed in different colors on the paper maps. 


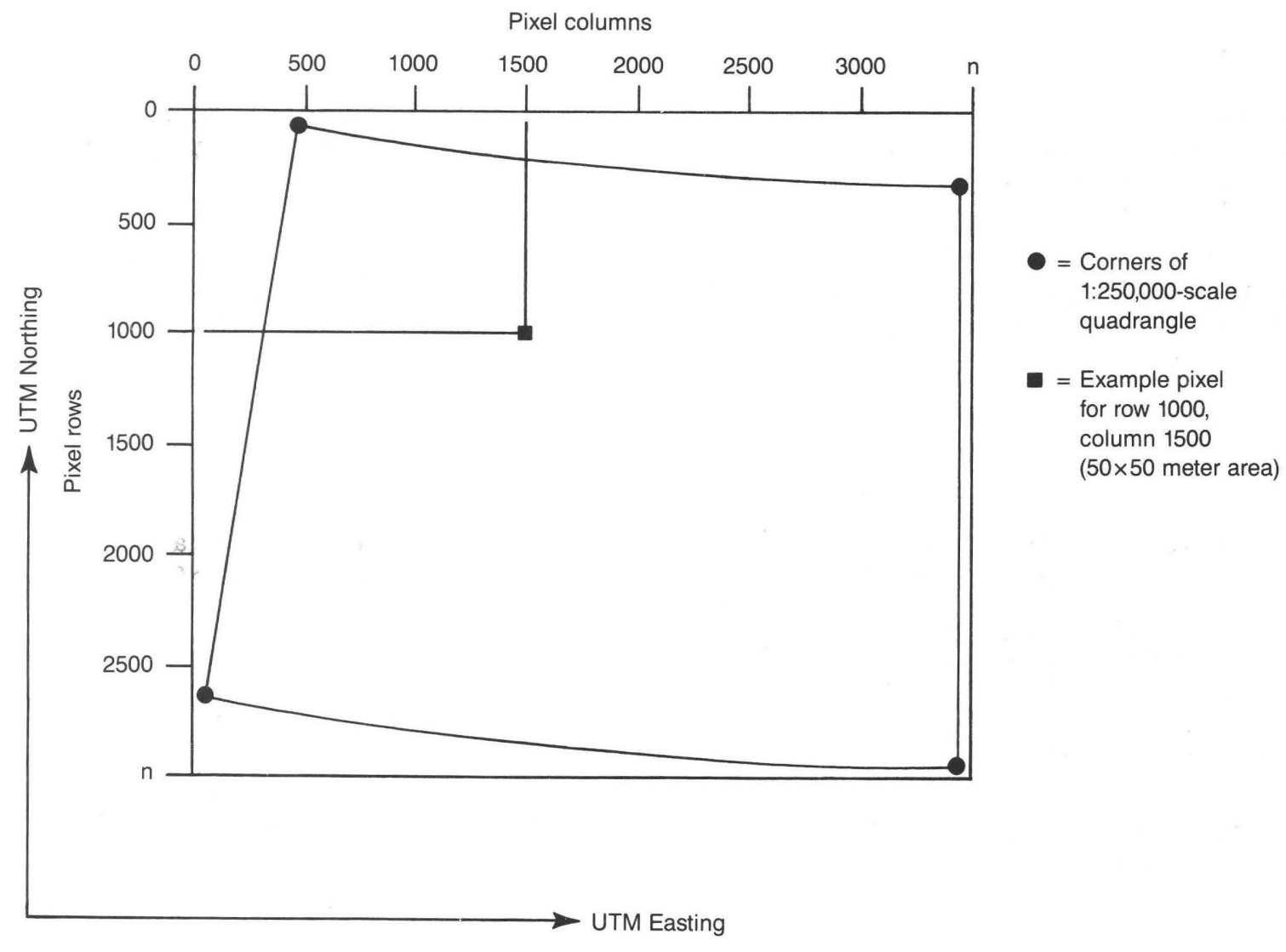

Figure 1.--Structure of Alaska land cover data.

DATA FORMATS

The format of the Alaska Landsat land cover tapes was designed to meet the tape format specifications developed by the Landsat Ground Station Operators Working Group (Landsat-D CCT standards committee, 1979). It incorporates the required descriptive superstructure records in addition to the classified Landsat digital image data.

Data are recorded on multifile 9-track magnetic tape in odd parity at 1600 bpi. Three files are included for each quadrangle (Appendix A). The first is a volume directory file that generally describes the tape. It contains three 360-byte records: a volume descriptor record containing references to relevant documentation and tape creation information, and two file pointer records containing format information for the following two files. These three records conform to the superstructure record specifications noted above.

The second file is a leader file containing information used to interpret the image data. Like the first file, all leader file records are 360 bytes long. The first record is a file descriptor record that provides additional format information. Bytes 181-196 of this record contain values for the number of records used to describe items that will vary in number between tapes, and so indicate the length of the file. 
The remainder of the records in the leader file contain descriptive information in card image format. The second, third, and fourth records identify the area covered by the image data, the size of the image file, pixel size, and image projection. The next set of records identifies each of the Landsat scenes used in the compilation of the data. Following that are records identifying the registration tick mark coordinates used to register the image to the proper map. The next set of records lists and describes each of the land cover classes used in the image data. A final set of records contains additional, nonstructured comments about the image data.

The third file contains the image data described by the preceding leader file. The first record is a file descriptor record that meets the superstructure record specifications. Bytes 181-192 of this record contain image size and number of land cover classes so that, if necessary, the data can be read and displayed without reading the leader file. The remaining records contain the image data with the number of records equal to the number of image rows and the record length equal to the number of image columns. (The file descriptor record is padded to this length with blanks so that the file contains only fixed-length records.) Each 8-bit byte represents an integer number in binary number representing the coded land cover class for that cell.

The end of the tape is indicated with a null volume descriptor record and three End of File indicators.

\section{APPLICATIONS}

The Alaska land cover tapes have tremendous potential for regional landscape studies. They can be used in hydrologic and wildlife habitat studies and as a base for assessing impact of new development. Statistical summaries of the extent of cover types of the present landscape can provide a quantitative base for inferences regarding geomorphological changes. These data can also be used in combination with digital elevation models (DEM) (Elassal and Caruso, 1984) to correlate land cover and topographic features. In conjunction with still more layers of information, these data form the basis for a geographic information system. The simple format of the data should allow use on most image processing or information systems.

The land cover and vegetation maps being prepared from the data are a prime application of the data. The classified data for one 1:250,000scale quadrangle are used to generate color-separated plates for printing a land cover map. The plates are registered to existing scribed base layers containing projection lines, public land survey system, cultural features, and place names. These are combined with the map collar information and printed on the front of the map. Statistical summaries of the extent of each land cover unit in each township cell are printed on the reverse side of the map. 


\section{ACCURACY}

No comprehensive, controlled, systematic checks of the accuracy of all the land cover data have been conducted, although checks for specific areas have been done. Ground data and aerial photographs have been used as reference for controlling the classification, and the resulting classes are generally consistent with those sources. The Geological survey does not assume any responsibility for the accuracy of the tapes, but does solicit comments from users that may help to improve the data for future revision.

\section{REFERENCES}

Anderson, J.R., Hardy, E.E., Roach, J.R., and Witmer, R.E., 1976, A land use and land cover classification system for use with remote sensor data: U.S. Geological Survey Professional Paper 964, 28 p.

Elassal, A.A., and Caruso, V.M., 1984, Digital elevation models: U.S. Geological Survey Circular 895-B, 40 p. [USGS Digital Data Standards, edited by McEwen, R.B., Witmer, R.E., and Ramey, B.S.]

Landsat-D CCT standards committee, Landsat Ground Station Operators Working Group, 1979, LGSOWG CCT format CCB document: The standard CCT family of tape formats, Doc. No. CCB-CCT-0002E: Landsat Operations Division, Greenbelt, MD.

Viereck, L.A. and Dyrness, C.T., 1980, A preliminary classification system for vegetation of Alaska: U.S. Department of Agriculture, Forest Service, Pacific Northwest Forest and Range Experiment Station, General Technical Report PNW-106, 38 p. 

APPENDIX 
This appendix describes the contents of the Alaska Interim Mapping Program land cover tape files in detail. Each of the three files included in the land cover data set for one 1:250,000-scale quadrangle is described down to the byte level.

A blank "Contents" field in any of the record descriptions indicates information which will be specific to a data set. The character " is used to indicate embedded blanks where they might not be evident in context. Any numbers followed by $/ 8$ are assumed to be octal values. Each quadrangle name is abbreviated to 12 characters, if necessary. This "sheet-abbreviation" is used to form the file names of the various files on the tape.

Each tape will contain information in the order described immediately below (record length in parentheses).

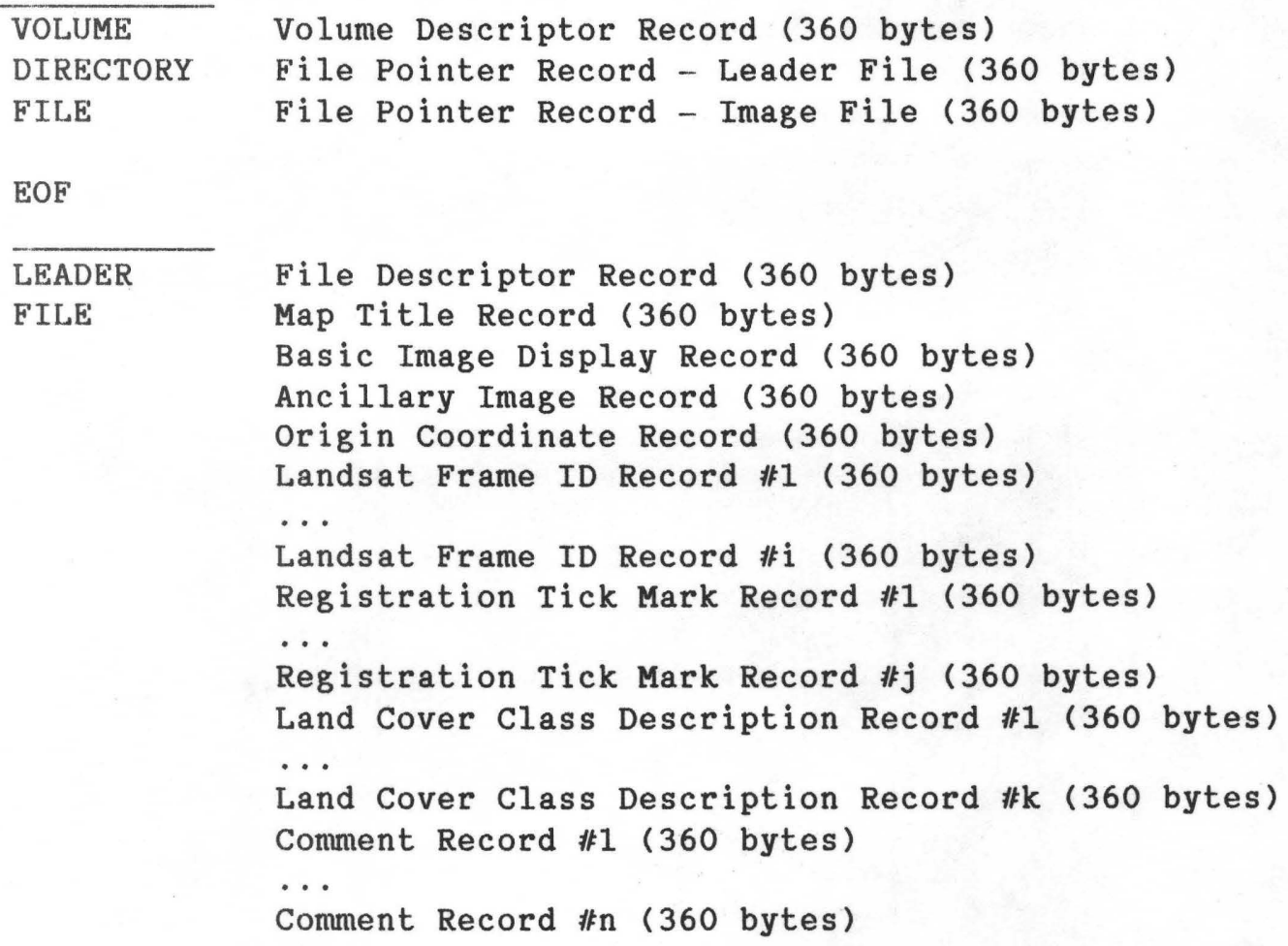

File Descriptor Record (360 bytes)

Map Title Record ( 360 bytes)

Basic Image Display Record ( 360 bytes)

Ancillary Image Record ( 360 bytes)

Origin Coordinate Record ( 360 bytes)

Landsat Frame ID Record 非 ( 360 bytes)

...

Landsat Frame ID Record 非 ( 360 bytes)

Registration Tick Mark Record \#1 (360 bytes)

...

Registration Tick Mark Record 非 (360 bytes)

Land Cover Class Description Record 非 ( 360 bytes)

...

Land Cover Class Description Record 非 (360 bytes)

Comment Record 非 (360 bytes)

...

Comment Record 非 (360 bytes)

File Descriptor Record (number of pixels across image) Image Data Records (each, number of pixels across image) 


\begin{tabular}{l} 
NULL \\
VOLUME \\
DESCRIPTOR \\
RECORD \\
EOF \\
\hline EOF \\
EOF \\
\hline
\end{tabular}

Volume Directory File

Volume Descriptor Record

This section describes the format of the first record of the Volume Directory File.

\begin{tabular}{|c|c|c|c|}
\hline Field & Bytes & Contents & Description \\
\hline 1 & $1-4$ & $\leadsto 1$ & $\begin{array}{l}\text { Record sequence number within } \\
\text { file }\end{array}$ \\
\hline 2 & 5 & $300) 8$ & \\
\hline 3 & 6 & $3 0 0 \longdiv { 8 }$ & Record \\
\hline 4 & 7 & $022) 8$ & Type \\
\hline 5 & 8 & $022) 8$ & Code \\
\hline 6 & $9-12$ & 360 & Record length in bytes \\
\hline 7 & $13-14$ & $A^{n}$ & ASCII record indicator \\
\hline 8 & $15-16$ & a. & Always left blank \\
\hline 9 & $17-28$ & CCB-CCT-002 & Format Control Document \\
\hline 10 & $29-30$ & $\mathrm{C}^{\wedge}$ & $\begin{array}{l}\text { Format Control Document } \\
\text { Revision }\end{array}$ \\
\hline 11 & $31-32$ & ${ }^{\wedge} \mathrm{A}$ & Record Format Revision Letter \\
\hline 12 & $33-44$ & & Software Release Number \\
\hline 13 & $45-60$ & AKLCsheet-abbreviation & 16 character tape ID \\
\hline 14 & $61-76$ & AKLCsheet-abbreviation & 16 character logical volume ID \\
\hline 15 & $77-92$ & AKLCsheet-abbreviation & 16 character volume set ID \\
\hline 16 & $93-94$ & ^1 & Number of volumes in the set \\
\hline 17 & $95-96$ & ${ }^{\wedge} 1$ & Start of logical volume \\
\hline 18 & $97-98$ & ${ }^{\wedge} 1$ & End of logical volume \\
\hline 19 & $99-100$ & 1 & Tape number containing VDF \\
\hline 20 & $101-104$ & $\leadsto 1$ & $\begin{array}{l}\text { First referenced file number } \\
\text { in the physical volume }\end{array}$ \\
\hline 21 & $105-108$ & $\cdots 1$ & $\begin{array}{l}\text { Volume number within volume } \\
\text { set }\end{array}$ \\
\hline 22 & $109-112$ & $\leadsto 1$ & $\begin{array}{l}\text { Volume number within physical } \\
\text { volume }\end{array}$ \\
\hline 23 & $113-120$ & & Date of tape creation YYYYMMDD \\
\hline
\end{tabular}


Volume Directory File--..continued

Volume Descriptor Record

\begin{tabular}{|c|c|c|c|}
\hline Field & Bytes & Contents & Description \\
\hline 24 & $121-128$ & & Time of tape creation HHMMSSXX \\
\hline 25 & $129-140$ & $\mathrm{USA}^{\wedge}{ }^{\wedge}{ }^{\wedge}$ & Generating country \\
\hline 26 & $141-148$ & USGS/NMD & Generating Agency \\
\hline 27 & $149-160$ & & Generating Facility \\
\hline 28 & $161-164$ & $\leadsto \wedge 2$ & $\begin{array}{l}\text { Number of pointer records in } \\
\text { VDF }\end{array}$ \\
\hline 29 & $165-168$ & $\wedge \wedge 3$ & Number of records in VDF \\
\hline 30 & $169-260$ & blanks & Spare Segment - Reserved \\
\hline 31 & $261-360$ & blanks & Local Use Segment \\
\hline
\end{tabular}

File Pointer Record - Leader File

This section describes the format of the second record in the Volume Directory File.

\begin{tabular}{|c|c|c|c|}
\hline Field & Bytes & Contents & Description \\
\hline 1 & $1-4$ & $\leadsto \wedge 2$ & $\begin{array}{l}\text { Record sequence number within } \\
\text { file }\end{array}$ \\
\hline 2 & 5 & $333) 8$ & \\
\hline 3 & 6 & $300) 8$ & Record \\
\hline 4 & 7 & $022) 8$ & Type \\
\hline 5 & 8 & $022) 8$ & Code \\
\hline 6 & $9-12$ & 360 & Record length in bytes \\
\hline 7 & $13-14$ & $A^{n}$ & ASCII record indicator \\
\hline 8 & $15-16$ & 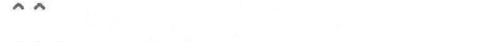 & Always left blank \\
\hline 9 & $17-20$ & $\cdots \wedge 1$ & Leader file number \\
\hline 10 & $21-36$ & LEADsheet-abbreviation & 16 character leader file name \\
\hline 11 & $37-64$ & AKLC LEADER FILE & File type \\
\hline 12 & $65-68$ & LEAD & File type code \\
\hline 13 & $69-96$ & 8 BIT ASCII ONLY & File data type \\
\hline 14 & $97-100$ & ASCO & File data type code \\
\hline 15 & $101-108$ & & Number of records in the file \\
\hline 16 & $109-116$ & 360 & Leader file - length of FDR \\
\hline 17 & $117-124$ & 360 & $\begin{array}{l}\text { Leader file - maximum record } \\
\text { length }\end{array}$ \\
\hline 18 & $125-136$ & FIXED LENGTH & Record length type \\
\hline 19 & $137-140$ & FXLN & Record length type code \\
\hline 20 & $141-142$ & ${ }^{\wedge} 1$ & $\begin{array}{l}\text { Physical volume number, start } \\
\text { of the file }\end{array}$ \\
\hline 21 & $143-144$ & ${ }^{\wedge} 1$ & $\begin{array}{l}\text { Physical volume number, end } \\
\text { of the file }\end{array}$ \\
\hline 22 & $145-152$ & $\leadsto \wedge_{1}$ & $\begin{array}{l}\text { First record number of the } \\
\text { file on this physical volume }\end{array}$ \\
\hline
\end{tabular}


File Pointer Record - Leader File--continued

\begin{tabular}{llll}
\hline Field & Bytes & Contents & Description \\
\hline 23 & $153-260$ & blanks & \multicolumn{1}{c}{ Local Use Segment } \\
24 & $261-264$ & & $\begin{array}{l}\text { Spare Segment - Reserved } \\
\text { Number of Landsat scene } \\
\text { records }\end{array}$ \\
25 & $265-268$ & $\begin{array}{l}\text { Number of registration tick } \\
\text { mark records }\end{array}$ \\
26 & $269-272$ & Number of land cover class \\
& & description records \\
27 & $273-276$ & Number of comment records & \\
28 & $277-360$ & blanks & \\
\hline
\end{tabular}

File Pointer Record - Image File

This section describes the format of the third record of the Volume Directory File.

\begin{tabular}{|c|c|c|c|}
\hline Field & Bytes & Contents & Description \\
\hline $\begin{array}{l}1 \\
\text { file }\end{array}$ & $1-4$ & $\leadsto \wedge 3$ & Record sequence number within \\
\hline 2 & 5 & $333) 8$ & \\
\hline 3 & 6 & $300) 8$ & Record \\
\hline 4 & 7 & $022) 8$ & Type \\
\hline 5 & 8 & $022) 8$ & Code \\
\hline 6 & $9-12$ & 360 & Record length in bytes \\
\hline 7 & $13-14$ & $A^{\wedge}$ & ASCII record indicator \\
\hline 8 & $15-16$ & ^^ & Always left blank \\
\hline 9 & $17-20$ & $\cdots 2$ & Image file number \\
\hline 10 & $21-36$ & IMAGsheet-abbreviation & 16 character image file name \\
\hline 11 & $37-64$ & ALASKA DIGITAL LAND COVE & Rile troe \\
\hline 12 & $65-68$ & AKLC & File type code \\
\hline 13 & $69-96$ & BINARY ONLY & File data type \\
\hline 14 & $97-100$ & BINO & File data type code \\
\hline 15 & $101-108$ & \# pixel rows +1 & Number of records in the file \\
\hline 16 & $109-116$ & 非 pixel columns & Image file - length of FDR \\
\hline 17 & $117-124$ & \# pixel columns & $\begin{array}{l}\text { Image file - maximum record } \\
\text { length }\end{array}$ \\
\hline 18 & $125-136$ & FIXED LENGTH & Record length type \\
\hline 19 & $137-140$ & FXLN & Record length type code \\
\hline 20 & $141-142$ & ${ }^{\wedge} 1$ & $\begin{array}{l}\text { Physical volume number, start } \\
\text { of the file }\end{array}$ \\
\hline 21 & $143-144$ & ${ }^{\wedge} 1$ & $\begin{array}{l}\text { Physical volume number, end } \\
\text { of the file }\end{array}$ \\
\hline 22 & $145-152$ & $\leadsto \ldots \wedge 1$ & $\begin{array}{l}\text { First record number of the } \\
\text { file on this tape }\end{array}$ \\
\hline
\end{tabular}


File Pointer Record - Image File--continued

\begin{tabular}{llll}
\hline Field & Bytes & Contents & Description \\
\hline & & & Local Use Segment \\
23 & $153-260$ & blanks & Spare Segment - Reserved \\
24 & $261-284$ & & 24 character quadrangle name \\
25 & $285-288$ & & Number of rows in the image \\
26 & $289-292$ & & Number of column in the image \\
27 & $293-294$ & & Number of land cover classes \\
28 & $295-360$ & blanks &
\end{tabular}

Leader File

File Descriptor Record

This section describes the format of the first record of the Leader File.

\begin{tabular}{|c|c|c|c|}
\hline Field & Bytes & Contents & Description \\
\hline 1 & $1-4$ & $\leadsto \wedge 1$ & $\begin{array}{l}\text { Record sequence number within } \\
\text { file }\end{array}$ \\
\hline 2 & 5 & $077) 8$ & \\
\hline 3 & 6 & $300) 8$ & Record \\
\hline 4 & 7 & $0 2 2 \longdiv { 8 }$ & Type \\
\hline 5 & 8 & $022) 8$ & Code \\
\hline 6 & $9-12$ & 360 & Record length in bytes \\
\hline 7 & $13-14$ & $A^{\wedge}$ & ASCII record indicator \\
\hline 8 & $15-16$ & $\leadsto$ & Always left blank \\
\hline 9 & $17-28$ & this document & Control Document Number \\
\hline 10 & $29-30$ & this document revision & $\begin{array}{l}\text { Control Document Number } \\
\text { Revision }\end{array}$ \\
\hline 11 & $31-32$ & & File Format Revision Number \\
\hline 12 & $33-44$ & & Software Release Number \\
\hline 13 & $45-48$ & $\leadsto \wedge 1$ & File number (excluding VDF) \\
\hline 14 & $49-64$ & LEADsheet-abbreviation & $\begin{array}{l}16 \text { character file name (same } \\
\text { as FPR field 10) }\end{array}$ \\
\hline 15 & $65-68$ & NSEQ & No sequence numbers in records \\
\hline 16 & $69-76$ & blanks & \\
\hline 17 & $77-80$ & blanks & \\
\hline 18 & $81-84$ & NTYP & $\begin{array}{l}\text { No record type codes in } \\
\text { records }\end{array}$ \\
\hline 19 & $85-92$ & blanks & \\
\hline 20 & $93-96$ & blanks & \\
\hline 21 & $97-100$ & NLGT & $\begin{array}{l}\text { No length indicators in } \\
\text { records }\end{array}$ \\
\hline 22 & $101-108$ & blanks & \\
\hline 23 & $109-112$ & blanks & \\
\hline
\end{tabular}


Leader File--continued

File Descriptor Record

\begin{tabular}{|c|c|c|c|}
\hline Field & Bytes & Contents & Description \\
\hline 24 & 113 & $\mathrm{Y}$ & $\begin{array}{l}\text { File interpretation } \\
\text { information is in the } \\
\text { Variable segment }\end{array}$ \\
\hline 25 & 114 & $\mathbf{N}$ & $\begin{array}{l}\text { File interpretation } \\
\text { information is not in the } \\
\text { Leader file }\end{array}$ \\
\hline 26 & 115 & $\mathrm{Y}$ & $\begin{array}{l}\text { Information to display the } \\
\text { file is in the Variable } \\
\text { Segment }\end{array}$ \\
\hline 27 & 116 & $\mathbf{N}$ & $\begin{array}{l}\text { Information to display the } \\
\text { file is not in the Leader file }\end{array}$ \\
\hline 28 & $117-180$ & blanks & Spare Segment - Reserved \\
\hline & & & Variable segment \\
\hline 29 & $181-184$ & & $\begin{array}{l}\text { Number of Landsat scene } \\
\text { records }\end{array}$ \\
\hline 30 & $185-188$ & & $\begin{array}{l}\text { Number of registration tick } \\
\text { mark records }\end{array}$ \\
\hline 31 & $189-192$ & & $\begin{array}{l}\text { Number of land cover class } \\
\text { description records }\end{array}$ \\
\hline 32 & $193-196$ & & Number of comment records \\
\hline 33 & $197-360$ & blanks & \\
\hline
\end{tabular}

Leader File Data Records

This section describes the format of the remaining records of the Leader file. These records contain information encoded in ASCII and so can be typed or printed directly. All records are 360 bytes in length, padded to the full length by blanks, if necessary. Underlined words are examples of data set-specific information.

\section{Record Number Contents}

2

3
Complete title of the map area covered by the image data.

E.g., SAGAVANIRKTOK 1:250,000 QUADRANGLE

Basic image display information.

E.g., IMAGE ROWS $=\underline{2500}$; IMAGE COLUMNS=2750; NUMBER OF LAND COVER CLASSES $=\underline{7}$ 
Leader File Data Records--continued

\begin{tabular}{|c|c|}
\hline Record Number & Contents \\
\hline 4 & $\begin{array}{l}\text { Ancillary non-variable length image information. } \\
\text { E.g., CELL SIZE }=50 \text { METERS; UTM ZONE }=\underline{6}\end{array}$ \\
\hline 5 & $\begin{array}{l}\text { Coordinates of } 0,0 \text { pixel (used for image registration). } \\
\text { E.g., COORDINATES OF } 0,0 \text { PIXEL: UTM }=496850 \\
\text { Easting, } 7775000 \text { Northing; LATITUDE }=70.0 \mathrm{~N} \text {; } \\
\text { LONGITUDE }=148.0 \mathrm{~W}\end{array}$ \\
\hline $6-6+i$ & $\begin{array}{l}\text { LANDSAT scene identification records for the } i \text { scenes } \\
\text { used; } \\
\text { listed in decreasing order of importance. } \\
\text { E.g., LANDSAT SCENE }=2170-20340\end{array}$ \\
\hline $6+i-6+i+j$ & $\begin{array}{l}\text { Registration tick mark records for the } j \text { tick marks } \\
\text { used; } \\
\text { each tick mark is assigned a labelling letter. } \\
\text { E.g. TICK MARK } \text {; LATITUDE }=69.3567 \text { DEG N; } \\
\text { LONGITUDE' }=146.2007 \text { DEG W; ROW VALUE }=2001 \text {; COLUMN } \\
\text { VALUE }=1579\end{array}$ \\
\hline $6+i+j-6+i+j+k$ & $\begin{array}{l}\text { Land cover class description records for the k classes } \\
\text { used; } \\
\text { classes are labelled numerically and are listed in } \\
\text { increasing order. Only those land cover classes } \\
\text { present in the data set will be described. Note that } \\
\text { the complete interim classification system contains } \\
\text { nineteen classes. } \\
\text { E.g., LAND COVER CLASS=4; TALL AND LOW SHRUBLANDS }\end{array}$ \\
\hline $\begin{array}{r}6+i+j+k- \\
6+i+j+k+n\end{array}$ & $\begin{array}{l}\text { Comment records for the } \mathrm{n} \text { comments to be made. } \\
\text { E.g., COMMENT =GROUND TRUTH DATA PROVIDED BY INSTAAR, } \\
\text { UNIVERSITY OF COLORADO }\end{array}$ \\
\hline
\end{tabular}

Image File

File Descriptor Record

This section describes the first record of the Image File. This record is as long as the image data records which follow. All records in this file should equal the maximum record length which is equal to the maximum number of cells across the image. The File Descriptor Record is padded with blanks to fit this length. The record length of image files will then vary from quadrangle to quadrangle. 
Image File-continued

File Descriptor Record

\begin{tabular}{|c|c|c|c|}
\hline Field & Bytes & Contents & Description \\
\hline 1. & $1-4$ & $\leadsto \wedge 1$ & $\begin{array}{l}\text { Record sequence number within } \\
\text { file }\end{array}$ \\
\hline 2 & 5 & $077) 8$ & \\
\hline 3 & 6 & $300) 8$ & Record \\
\hline 4 & 7 & $022) 8$ & Type \\
\hline 5 & 8 & $0 2 2 \longdiv { 8 }$ & Code \\
\hline 6 & $9-12$ & & Record length in bytes \\
\hline 7 & $13-14$ & $A^{\wedge}$ & ASCII record indicator \\
\hline 8 & $15-16$ & $\wedge \wedge$ & Always left blank \\
\hline 9 & $17-28$ & this document & Control Document Number \\
\hline 10 & $29-30$ & this document revision & $\begin{array}{l}\text { Control Document Revision } \\
\text { Number }\end{array}$ \\
\hline 11 & $31-32$ & & File Format Revision Number \\
\hline 12 & $33-44$ & & Software Release Number \\
\hline 13 & $45-48$ & $\cdots a^{\cdots}$ & File number (excluding VDF) \\
\hline 14 & $49-64$ & IMAGsheet-abbreviation & $\begin{array}{l}16 \text { character file name (same } \\
\text { as FPR Field 10) }\end{array}$ \\
\hline 15 & $65-68$ & NSEQ & No sequence numbers in records \\
\hline 16 & $69-76$ & blanks & \\
\hline 17 & $77-80$ & blanks & \\
\hline 18 & $81-84$ & NTYP & $\begin{array}{l}\text { No record type codes in } \\
\text { records }\end{array}$ \\
\hline 19 & $85-92$ & blanks & \\
\hline 20 & $93-96$ & blanks & \\
\hline 21 & $97-100$ & NLGT & No record lengths in records \\
\hline 22 & $101-108$ & blanks & \\
\hline 23 & $109-112$ & blanks & \\
\hline 24 & 113 & $\mathbf{N}$ & $\begin{array}{l}\text { File interpretation } \\
\text { information is not in the } \\
\text { Variable segment }\end{array}$ \\
\hline 25 & 114 & $\mathbf{N}$ & $\begin{array}{l}\text { File interpretation } \\
\text { information is not in the } \\
\text { Image File }\end{array}$ \\
\hline 26 & 115 & $\mathrm{Y}$ & $\begin{array}{l}\text { Information to display the } \\
\text { file is in the Variable } \\
\text { Segment }\end{array}$ \\
\hline 27 & 116 & $\mathrm{~N}$ & $\begin{array}{l}\text { Information to display the } \\
\text { file is not in the Image File }\end{array}$ \\
\hline 28 & $117-180$ & blanks & Spare Segment - Reserved \\
\hline & & & Variable Segment \\
\hline 29 & $181-184$ & & Number of rows in the image \\
\hline 30 & $185-188$ & & Number of columns in the image \\
\hline 31 & 189-192 & & Number of land cover classes \\
\hline 32 & 193-EOR & blanks & \\
\hline
\end{tabular}


The remaining records of the Image file contain the coded land cover data. Each record has length equal to the number of cells across the image. There is one record of this length for every row of cells in the image.

Each byte of a land cover data record contains a binary integer corresponding to the land cover unit present at that location.

\section{Null Volume Descriptor Record}

This section describes the format of the only record in the Null Volume Descriptor file.

\begin{tabular}{|c|c|c|c|}
\hline Field & Bytes & Contents & Description \\
\hline 1 & $1-4$ & $\leadsto{ }^{\wedge} 1$ & Record sequence number \\
\hline 2 & 5 & $3 0 0 \longdiv { 8 }$ & \\
\hline 3 & 6 & $300) 8$ & Record \\
\hline 4 & 7 & $077) 8$ & Type \\
\hline 5 & 8 & $022) 8$ & Code \\
\hline 6 & $9-12$ & 360 & Record length in bytes \\
\hline 7 & $13-14$ & $A^{\wedge}$ & ASCII record indicator \\
\hline 8 & $15-16$ & 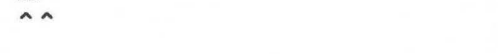 & Always left blank \\
\hline 9 & $17-28$ & CCB-CCT-0002 & $\begin{array}{l}\text { Superstructure Control } \\
\text { Document }\end{array}$ \\
\hline 10 & $29-30$ & $\mathrm{C}^{\wedge}$ & Control Document Revision \\
\hline 11 & $31-32$ & ${ }^{\wedge} \mathrm{A}$ & Record Format Revision \\
\hline 12 & $33-44$ & Software Release Number & \\
\hline 13 & $45-60$ & AKLCsheet-abbreviation & 16 character tape ID \\
\hline 14 & $61-76$ & blanks & \\
\hline 15 & $77-92$ & AKLCsheet-abbreviation & 16 character volume set ID \\
\hline 16 & $93-94$ & 1 & Number of tapes in the set \\
\hline 17 & $95-96$ & ${ }^{\wedge} 1$ & $\begin{array}{l}\text { Tape number, start of logical } \\
\text { volume }\end{array}$ \\
\hline 18 & $97-98$ & $\wedge 1$ & $\begin{array}{l}\text { Tape number, end of logical } \\
\text { volume }\end{array}$ \\
\hline 19 & $99-100$ & $\wedge 1$ & $\begin{array}{l}\text { Tape number containing this } \\
\text { record }\end{array}$ \\
\hline 20 & $101-104$ & $\wedge \wedge 1$ & $\begin{array}{l}\text { First referenced file in } \\
\text { physical volume }\end{array}$ \\
\hline 21 & $105-108$ & $\leadsto \wedge 1$ & Volume number within the set \\
\hline 22 & $109-112$ & $\wedge \wedge 1$ & $\begin{array}{l}\text { Logical volume number within } \\
\text { physical volume }\end{array}$ \\
\hline 23 & $113-120$ & blanks & \\
\hline 24 & $121-128$ & blanks & \\
\hline 25 & $129-140$ & blanks & \\
\hline 26 & $141-148$ & blanks & \\
\hline 27 & $149-160$ & blanks & \\
\hline 28 & $161-164$ & blanks & \\
\hline 29 & $165-168$ & blanks & \\
\hline 30 & $169-260$ & blanks & Spare Segment - Reserved \\
\hline 31 & $261-360$ & blanks & Local Use Segment \\
\hline
\end{tabular}

